\title{
DETEKSI ES DAN HAIL DI ATMOSFER DENGAN RADAR POLARIMETRIK X-BAND FURUNO WR-2100 (STUDI KASUS: 24 JANUARI DAN 14 FEBRUARI 2016)
}

\author{
Detection of Atmospheric Ice and Hail \\ with Furuno WR-2100 X-Band Polarimetric Radar \\ (Case Study: January $24^{\text {th }}$ and February $14^{\text {th }} 2016$ )
}

\author{
Ardhi Adhary Arbain ${ }^{1)^{*}}$, Faisal Sunarto ${ }^{2)}$, Erwin Mulyana ${ }^{3)}$ \\ 1,2,3) Balai Besar Teknologi Modifikasi Cuaca - Badan Pengkajian dan Penerapan Teknologi, Gedung Ir. \\ Mohammad Soebagio, GEOSTECH (820), Kawasan PUSPIPTEK, Serpong, Tangerang \\ 1) Atmosphere and Ocean Research Institute (AORI), The University of Tokyo, Japan \\ *Email : ardhi.adhary@bppt.go.id
}

\begin{abstract}
Intisari
Informasi keberadaan es di atmosfer sangat penting, tidak hanya untuk studi meteorologi, namun juga untuk kegiatan modifikasi cuaca maupun pengembangan sistem peringatan dini bencana hidrometeorologi. Pada makalah ini, kami mendemonstrasikan tiga teknik deteksi es dengan memanfaatkan observasi radar X-band polarimetrik Furuno WR-2100. Data Constant Altitude Plan Position Indicator (CAPPI) untuk parameter horizontal reflectivity (Zh), differential reflectivity (ZDR) dan specific differential phase (KDP) pada kejadian presipitasi konvektif di wilayah Banten dan Bogor tanggal 24 Januari dan 14 Februari 2016 dianalisis dengan menggunakan metode Hail Differential Reflectivity (HDR), metode konsistensi KDP (CM) dan metode fuzzy logic (FL). Produk data yang dihasilkan oleh ketiga metode tersebut saling dibandingkan secara horizontal pada ketinggian 500 meter, 2 kilometer dan 5 kilometer, serta secara vertikal hingga ketinggian 15 kilometer. Hasil analisis menunjukkan metode HDR paling sensitif dan konsisten untuk identifikasi es pada setiap level ketinggian, sedangkan metode FL dapat membedakan jenis es secara spesifik. Di sisi lain, rendahnya sensitivitas metode CM dalam penelitian ini menunjukkan tidak adanya konsentrasi es yang signifikan pada waktu observasi dan mengindikasikan metode tersebut lebih sensitif untuk deteksi jenis es dengan ukuran yang lebih besar.
\end{abstract}

Kata Kunci : Deteksi, Hail, Es, Radar, Polarimetrik, CAPPI.

\begin{abstract}
The existence of ice in the atmosphere has proven to not only be an important piece of information in meteorological studies but also for weather modification activities and the development of hydrometeorological disaster early warning system. In this study, we present three ice detection algorithms by utilizing a Furuno WR-2100 polarimetric $x$-band radar. Constant Altitude Plan Position Indicator (CAPPI) data of horizontal reflectivity (Zh), differential reflectivity (ZDR) and specific differential phase (KDP) parameters of convective precipitation events over Banten and Bogor on January $24^{\text {th }}$ and Februari $14^{\text {th }} 2016$ were analyzed with the use of hail differential reflectivity method $(H D R), K D P$ consistency method (HP) and fuzzy logic method (FL). The resulting products were then compared horizontally at the altitude level of 500 meters, 2 kilometers and 5 kilometers, and vertically, up to 15 kilometers. The results shows that HDR is consistent and most sensitive in detecting ice at each altitude level, while the FL method is capable for specifically differentiating the ice types. On the other hand, the weak response of CM method indicates that there was no significant ice concentration at the observation time and the technique is more sensitive in detecting larger ice types.
\end{abstract}

Keywords : Detection, Hail, Ice, Radar, Polarimetric, CAPPI.

\section{PENDAHULUAN}

Radar cuaca merupakan salah satu instrumen penginderaan jauh yang digunakan untuk pengamatan presipitasi di atmosfer secara real-time. Radar cuaca memiliki keunggulan dalam mendeteksi distribusi presipitasi dalam ruang dan waktu karena memiliki resolusi spasial dan temporal yang jauh lebih tinggi dibandingkan penginderaan jauh dengan satelit. Informasi utama yang diperoleh dari pengamatan radar cuaca adalah intensitas dan kecepatan objek yang diamati (dalam hal ini presipitasi) terhadap posisi radar. Radar cuaca menggunakan sensor 
aktif yang menghasilkan gelombang elektromagnetik untuk mendeteksi distribusi presipitasi di atmosfer tanpa harus bergantung pada radiasi matahari seperti yang lazim digunakan pada pengamatan dengan satelit. Hal ini mendorong penggunaan radar cuaca secara luas, baik untuk keperluan penelitian dalam bidang meteorologi, maupun untuk peringatan dini bencana hidrometeorologi, misalnya untuk kejadian banjir atau hujan ekstrim di Indonesia (Arbain et al., 2017; Mori et al., 2011; Wu et al., 2013).

Sejak permulaan abad ke-21, teknologi radar polarimetrik atau polarisasi ganda yang sebelumnya lebih banyak digunakan untuk penilitian mikrofisika awan mulai digunakan untuk kegiatan operasional, menggantikan pengamatan dengan radar konvensional (Golbon-Haghighi et al., 2016; Grazioli et al., 2015; Ribaud et al., 2016). Berbeda dengan radar konvensional, radar polarimetrik menggunakan gelombang elektromagnetik dengan polarisasi horizontal dan vertikal. Karena objek presipitasi (selanjutnya akan disebut sebagai hydrometeor) umumnya tidak berbentuk bulat sempurna (spherical), maka sinyal balik yang diterima radar polarimetrik akan mengalami polarisasi, dengan intensitas dan karakter yang berbeda pada masing-masing kanal horizontal dan vertikal. Perbedaan pada kedua kanal ini dapat dimanfaatkan untuk menentukan ukuran, bentuk, arah maupun fase dari hydrometeor yang teramati, misalnya untuk membedakan hujan dengan hail atau es. Walaupun beberapa studi sebelumnya menunjukkan bahwa radar konvensional dapat digunakan untuk mendeteksi es di atmosfer (Ali \& Hidayati, 2015; Kunz \& Kugel, 2015; Witt \& Nelson, 1991), metode yang digunakan umumnya memiliki keterbatasan untuk mengidentifikasi fase hydrometeor dan terlalu kompleks untuk diaplikasikan pada kegiatan operasional. Pada penelitian ini, kami mendemonstrasikan tiga algoritma untuk deteksi es dan hail di atmosfer dengan menggunakan radar polarimetrik X-band Furuno WR-2100 yang dioperasikan oleh Balai Besar Teknologi Modifikasi Cuaca, Badan Pengkajian dan Penerapan Teknologi (BBTMC BPPT). Radar ini memiliki keunggulan pada sisi pengoperasian dan mobilitas karena ukurannya yang relatif lebih kecil dibandingkan radar polarimetrik lain dalam kelas yang sama. Namun di sisi lain, radar ini memiliki kekurangan dalam hal jangkauan dan produk akhir untuk klasifikasi jenis hydrometeor. Penelitian ini memanfaatkan hasil pengukuran beberapa parameter polarimetrik radar Furuno WR-2100 untuk mendeteksi keberadaan es dan hail di atmosfer dengan menggunakan metode yang lebih sederhana dibandingkan radar polarisasi tunggal, sehingga dapat dengan mudah diaplikasikan untuk berbagai kegiatan operasional, baik untuk peringatan dini maupun modifikasi cuaca.

\section{METODE}

\subsection{Data}

Data yang digunakan dalam makalah ini adalah produk Constant Altitude Plan Position Indicator (CAPPI) radar $\mathrm{X}$-band polarimetrik Furuno WR-2100, pada tanggal 24 Januari 2016 pukul 18:45 WIB dan 14 Februari 2016 pukul 13:55 WIB, yang bertepatan dengan periode kegiatan Intensive Observation Period (IOP) Balai Besar Teknologi Modifikasi Cuaca BPPT (BBTMC-BPPT) dan Badan Meteorologi Klimatologi dan Geofisika (BMKG). Pengamatan pada waktu-waktu tersebut dipilih karena adanya kejadian hujan konvektif di wilayah Banten dan Bogor dengan nilai reflektivitas tertinggi selama periode IOP, yang melebihi $45 \mathrm{dBZ}$. Daerah observasi radar yang dianalisis beserta waktu pengamatannya ditunjukkan pada gambar 1 .
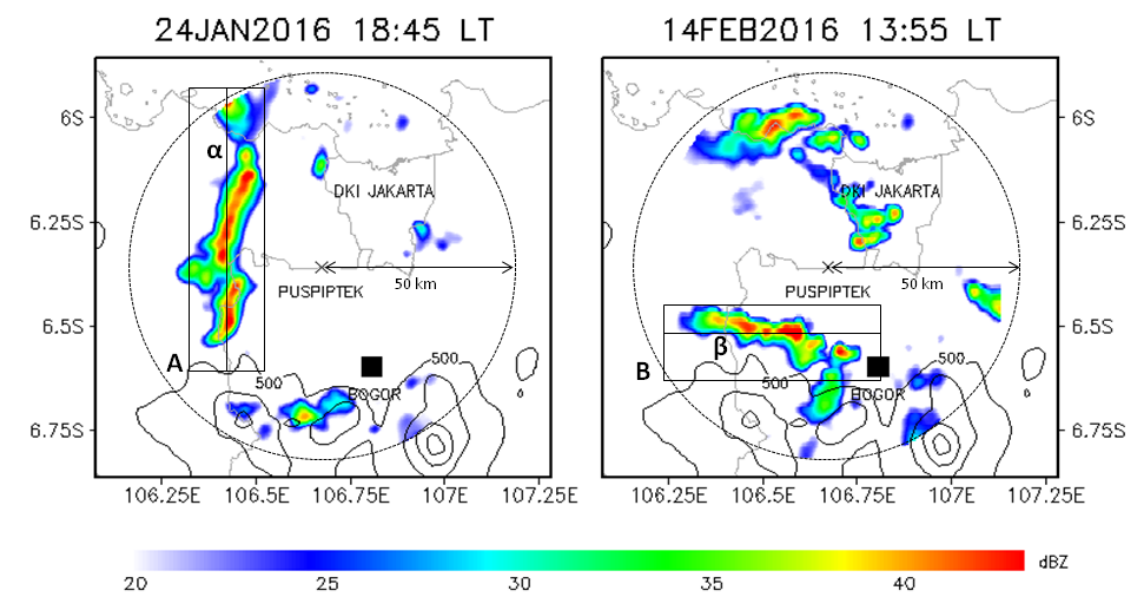

Gambar 1. Daerah presipitasi (shaded contour) pada tanggal 24 Januari 2016 pukul 18:45 WIB (panel

kiri, kotak A) dan 14 Februari 2016 pukul 13:55 WIB (panel kanan, kotak B). Garis $\alpha$ dan $\beta$ masingmasing menunjukkan daerah irisan vertikal untuk wilayah A dan B pada Gambar 10 dan Gambar 11. Peta kontur (non-shaded) menunjukkan elevasi daerah pengamatan, dalam satuan meter. 
Daerah presipitasi pada tanggal 24 Januari 2016 pukul 18:45 WIB ditunjukkan sebagai daerah di dalam kotak $A$ (selanjutnya disebut wilayah $A$ ), sedangkan daerah presipitasi pada tanggal 14 Februari 2016 pukul 13:55 WIB ditunjukkan sebagai daerah di dalam kotak B (selanjutnya disebut wilayah B). Produk CAPPI diperoleh dari pengamatan Horizontal Sequence Scan (HSQ) setiap 5 menit dengan 12 sudut elevasi. Spesifikasi radar dan konfigurasi pengamatan secara lengkap dapat dilihat pada studi yang dilakukan Arbain et al. (2017). Untuk validasi kejadian hujan es, kami menggunakan laporan SYNOP pada stasiun BMKG terdekat dengan lokasi observasi: stasiun Serang, stasiun Curug Budiarto dan Stasiun Citeko Bogor.

Untuk data binary radar (type-2 data), terdapat delapan jenis parameter yang dihasilkan pada setiap observasi, yaitu: rainfall intensity $(R)$, Doppler speed (V), spectral width (W), horizontal reflectivity (Zh), differential reflectivity (ZDR), differential phase shift $(\varphi \mathrm{dp})$, specific differential phase (KDP) dan correlation coefficient ( $\rho$ hv). Dari delapan parameter tersebut, empat yang terakhir merupakan produk khusus radar polarimetrik yang tidak dapat diperoleh dari radar konvensional (polarisasi tunggal). Untuk deteksi es pada studi ini, parameter radar yang digunakan adalah $\mathrm{Zh}$, ZDR dan KDP.

Zh atau Z (pada radar konvensional), merupakan faktor reflektivitas pada kanal horizontal, yang merupakan perbandingan antara sinyal radar yang dipantulkan oleh suatu objek (dalam $\mathrm{mm}^{6} / \mathrm{m}^{3}$ ) dengan tetes hujan dengan diameter $1 \mathrm{~mm}$ (atau $1 \mathrm{~mm} / \mathrm{m}^{3}$ ). Zh sebanding dengan jumlah tetes (droplet) per satuan volume dan pangkat enam dari diameternya, sehingga dapat digunakan untuk memperkirakan intensitas presipitasi, seperti hujan, es maupun salju. Berdasarkan distribusi diameter eksponensial objek, parameter $\mathrm{Zh}$ dapat diekspresikan sebagai berikut:

$$
Z h=\int_{0}^{D \max } N_{0} e^{-ת D} D^{6} d D
$$

Karena orde satuan yang berbeda antara $\mathrm{Zh}(1 \mathrm{~mm} 6 / \mathrm{m} 3$ atau $1 \mathrm{um} 3)$ dengan diameter tetes air $(1 \mathrm{~mm})$ serta variasi nilai $\mathrm{Zh}$ yang sangat besar untuk tiap jenis hydrometeor, maka parameter ini dinyatakan dalam satuan logaritmik dBZ.

$$
d B Z=10 \log _{10} Z
$$

Nilai Zh sangat bergantung pada jumlah $(\mathrm{N})$ dan diameter (D) dari objek yang diamati. Secara fisis, nilai $\mathrm{Zh}$ yang tinggi menunjukkan jumlah objek yang teramati sangat banyak dan berdiameter besar, misalnya pada hujan dengan intensitas tinggi atau hujan es (hail). Parameter $\mathrm{Zh}$ dapat dikonversi ke dalam besaran intensitas hujan $(\mathrm{mm} / \mathrm{jam})$ dengan formula Marshall-Palmer.
ZDR merupakan salah satu parameter utama radar polarimetrik yang menunjukkan selisih antara reflektivitas yang diterima pada kanal horizontal (Zh) terhadap kanal vertikal (Zv), dalam satuan $\mathrm{dB}$. Sebagai catatan, data binary dari radar yang digunakan dalam studi ini hanya menghasilkan parameter Zh (tanpa Zv).

$$
\begin{aligned}
& Z D R=Z h-Z v \\
& Z D R=10 \log \left(\frac{Z h}{Z v}\right)
\end{aligned}
$$

ZDR merupakan salah satu parameter polarimetrik yang paling sering digunakan dalam berbagai metode untuk deteksi es di atmosfer. Nilai ZDR sangat penting dalam observasi radar untuk mengetahui bentuk objek yang diamati, misalnya untuk membedakan tetes air dengan es apabila keduanya memiliki nilai $\mathrm{Zh}$ yang sama. Tetes air pada hujan berintensitas tinggi umumnya lebih pipih (oblate) karena pengaruh gesekan udara, sedangkan es berbentuk lebih bulat (spherical) atau memanjang secara vertikal (prolate) seperti yang ditunjukkan pada gambar 2. Dengan demikian, nilai ZDR positif mengindikasikan objek yang teramati adalah tetes air, sedangkan nilai ZDR 0 atau negatif menunjukkan bahwa objek tersebut adalah es, partikel air (mengambang, $\mathrm{Zh}$ rendah) atau objek yang lain.

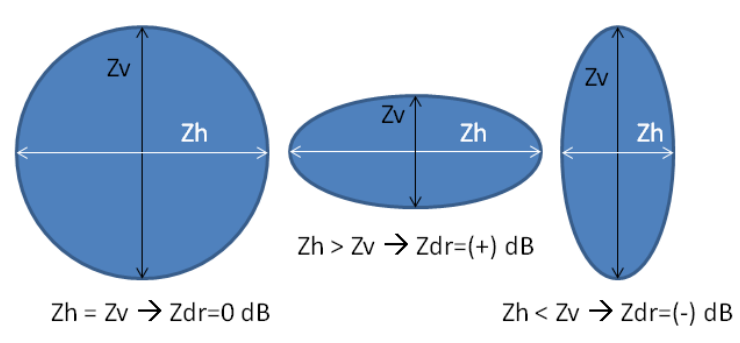

Gambar 2. Variasi nilai ZDR terhadap bentuk hydrometeor.

Parameter lain yang dapat digunakan untuk identifikasi es di atmosfer adalah KDP. Sinyal radar umumnya akan mengalami redaman ketika merambat melalui suatu objek di atmosfer, misalnya hujan atau es, dan hal ini menyebabkan pergeseran fase pada sinyal radar yang dipantulkan objek. Perbedaan pergeseran fase sinyal antara kanal horizontal dan vertikal radar dinyatakan oleh parameter $\varphi d p$. Karena nilai $\varphi d p$ akan meningkat dengan jarak antara radar dan objek, maka turunan $\varphi$ dp terhadap jarak ( $r 1, \mathrm{r} 2)$ dapat digunakan untuk menentukan posisi perubahan fase tersebut. Parameter turunan $\varphi d p$ ini adalah KDP, yang dinyatakan dengan satuan derajat $/ \mathrm{km}$.

$$
K D P=\frac{\varphi_{d p}\left(r_{2}\right)-\varphi_{d p}\left(r_{1}\right)}{2\left(r_{2}-r_{1}\right)}
$$


Seperti halnya ZDR, parameter KDP akan bernilai positif apabila perubahan fase lebih banyak pada arah horizontal, dan negatif bila lebih banyak pada arah vertikal. KDP positif umumnya lebih banyak disebabkan oleh adanya tetes hujan, sedangkan es atau salju umumnya tidak menyebabkan perubahan fase baik dalam arah horizontal maupun vertikal (KDP 0). Di sisi lain, $\varphi d p$ dan KDP juga sangat dipengaruhi oleh konsentrasi objek yang dilalui sinyal radar. Presipitasi berukuran kecil namun memiliki konsentrasi tinggi akan menyebabkan pergeseran fase yang lebih besar dibandingkan presipitasi berukuran besar namun rendah konsentrasinya.

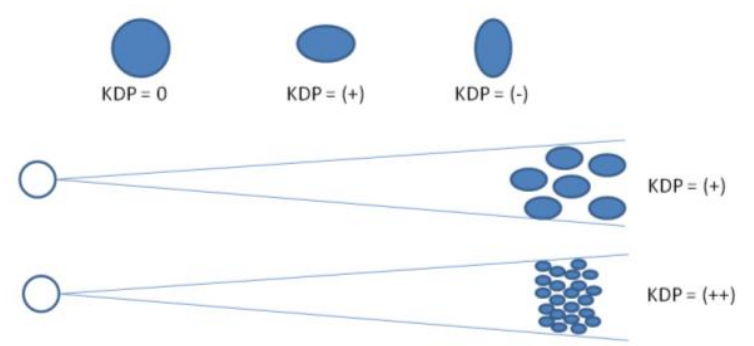

Gambar 3. Variasi nilai KDP terhadap bentuk dan konsentrasi hydrometeor

\subsection{Metode Reflektivitas Diferensial Hail (HDR)}

Algoritma ini diperkenalkan pertama kali oleh Leitao \& Watson (1984) dan disempurnakan oleh Aydin et al., (1986). Metode reflektivitas diferensial hail digunakan dengan menentukan daerah hujan pada medan Zh-ZDR dan menetapkan suatu garis batas yang disebut parameter reflektivitas diferensial hail (HDR) yang diperoleh melalui persamaan berikut:

$$
H D R=Z h-g(Z D R)
$$

di mana,

$$
\begin{aligned}
g(Z D R) & =27 d B & & Z D R<0 d B \\
& =19^{\star} Z D R+27 d B & & 0 \leq Z D R \leq 1.74 d B \\
& =60 d B & & Z D R>1.74 d B
\end{aligned}
$$

Rentang nilai g(ZDR) ditentukan berdasarkan pengamatan dengan disdrometer. Nilai HDR positif mengindikasikan kejadian hail, dengan probabilitas yang meningkat seiring dengan meningkatnya nilai HDR (Aydin et al., 1986; Vivekanandan et al., 1999).

\subsection{Metode Konsistensi (CM)}

Konsistensi antara nilai Zh, ZDR dan KDP dapat dimanfaatkan untuk menentukan nilai parameter yang satu berdasarkan nilai dua parameter yang lain. Misalnya, nilai KDP dapat diperkirakan berdasarkan nilai Zh dan ZDR (dalam satuan linear) (Vivekanandan et al., 2003), melalui persamaan berikut:

$$
K D P_{c}=3.32 * 10^{-5} Z h Z D R^{-2}
$$

Keberadaan hail akan menyebabkan tidakkonsistenan antara nilai $\mathrm{KDP}_{\mathrm{c}}$ dengan nilai $\mathrm{KDP}_{\mathrm{m}}$ yang diperoleh melalui pengamatan radar (Smyth et al., 1999). Parameter hail dapat ditentukan dengan:

$$
H P=K D P_{c}-K D P_{m}
$$

$\mathrm{KDP}_{\mathrm{c}}$ adalah nilai KDP yang diperoleh dari persamaan (7) berdasarkan distribusi radial $\mathrm{Zh}$ dan ZDR, sedangkan $\mathrm{KDP}_{\mathrm{m}}$ diperoleh dari pengamatan radar langsung. Keberadaan hail meningkatkan nilai $\mathrm{KDP}_{\mathrm{c}}$ dibandingkan $\mathrm{KDP}_{\mathrm{m}}$, sedangkan pada kejadian hujan, nilai $\mathrm{KDP}_{\mathrm{c}}$ dan $\mathrm{KDP}_{\mathrm{m}}$ relatif sama $\left(\mathrm{HP} \sim 0^{\circ} / \mathrm{km}\right)$. Nilai $\mathrm{HP}$ yang tinggi (positif) menunjukkan keberadaan hail yang signifikan pada daerah pengamatan radar.

\subsection{Metode Fuzzy Logic (FL)}

Hasil pengukuran parameter polarimetrik tidak selalu unik untuk tiap jenis hydrometeor, termasuk hail. Beberapa studi menunjukkan bahwa hail memiliki rentang nilai parameter yang beririsan dengan hujan maupun graupel, untuk $\mathrm{Zh}$, ZDR maupun KDP (Al-Sakka et al., 2013; Dolan \& Rutledge, 2009; Kouketsu et al., 2015; Mahale et al., 2014; Vivekanandan et al., 1999, 2003). Pendekatan dengan fuzzy logic (FL) dilakukan dengan menggunakan membership function (MF) untuk klasifikasi hydrometeor berdasarkan parameter polarimetrik radar. Misalnya, MB untuk hail 'murni' memiliki rentang nilai Zh antara $50 \mathrm{dBZ}$ sampai $70 \mathrm{dBZ}$, nilai ZDR antara $-2 \mathrm{~dB}$ sampai $+0.5 \mathrm{~dB}$ dan nilai $\mathrm{KDP}$ antara $-1 \% / \mathrm{km}$ sampai $1 \% \mathrm{~km}$.

Tabel 1. Rentang Klasifikasi Presipitasi untuk Metode Fuzzy Logic (FL).

\begin{tabular}{cllll}
\hline Indeks MF & Hydrometeor & Zh (dBZ) & ZDR (dB) & KDP $\left({ }^{\circ} \mathbf{k m}^{-1}\right)$ \\
\hline 1 & Gerimis (drizzle) & $0 \leq \mathrm{Zh} \leq 25$ & $-0.2 \leq \mathrm{ZDR} \leq 0.2$ & $-0.2 \leq \mathrm{KDP} \leq 0.2$ \\
\hline 2 & Hujan & $25 \leq \mathrm{Zh} \leq 60$ & $0.5 \leq \mathrm{ZDR} \leq 4$ & $0 \leq \mathrm{KDP} \leq 5$ \\
\hline 3 & Graupel & $40 \leq \mathrm{Zh} \leq 55$ & $-0.5 \leq \mathrm{ZDR} \leq 3$ & $-0.5 \leq \mathrm{KDP} \leq 2$ \\
\hline 4 & Campuran hujan-hail & $50 \leq \mathrm{Zh} \leq 70$ & $-1 \leq \mathrm{ZDR} \leq 1$ & $0 \leq \mathrm{KDP} \leq 2$ \\
\hline 5 & Hail & $50 \leq \mathrm{Zh} \leq 70$ & $-2 \leq \mathrm{ZDR} \leq 0.5$ & $-1 \leq \mathrm{KDP} \leq 1$ \\
\hline
\end{tabular}


Studi ini menggunakan beberapa MF 1 dimensi seperti yang ditunjukkan pada tabel 1 untuk klasifikasi hydrometeor, antara lain: hujan, hujan ringan, graupel, campuran hujan-hail dan hail (Al-Sakka et al., 2013; Dolan \& Rutledge, 2009; Kouketsu et al., 2015; Vivekanandan et al., 1999, 2003).Persamaan MF 1 dimensi untuk klasifikasi presipitasi dapat dinyatakan sebagai berikut :

$$
Q_{i}=\sum_{i} P_{i}(j) \cdot W_{i}
$$

$Q_{i}$ adalah nilai total MF untuk tiap jenis presipitasi, dimana $\mathrm{Pi}(\mathrm{j})$ adalah nilai MF untuk tiap jenis parameter radar polarimetrik yang digunakan, dan $\mathrm{W}_{\mathrm{i}}$ adalah bobot MF untuk tiap parameter tersebut. Nilai $P_{i}$ untuk tiap parameter diperoleh dengan normalisasi untuk tiap nilai yang terukur ke dalam rentang 0 sampai 1 . Normalisasi dihitung berdasarkan karakteristik hydrometeor yang bersangkutan. Misalnya untuk hail, nilai ZDR $-2 \mathrm{~dB}$ akan dinormalisasi ke nilai 1, sedangkan ZDR 0.5 $\mathrm{dB}$ akan dinormalisai ke nilai 0 . Nilai parameter di luar rentang klasifikasi akan bernilai 0 . Karena terdapat lima klasifikasi hydrometeor dalam penelitian ini, maka terdapat lima MF untuk tiap klasifikasi. Untuk penelitian ini, parameter $\mathrm{Zh}$ dan ZDR memiliki bobot yang sama ( $\mathrm{W}=1)$, sedangkan KDP memiliki bobot $0.5 \quad(\mathrm{~W}=0.5)$. Sehingga persamaan MF (10) di atas dapat dituliskan sebagai berikut.

$$
Q_{i}=P_{i} Z h+P_{i} Z D R+0.5\left(P_{i} K D P\right)
$$

Setelah nilai total $Q_{i}$ diperoleh untuk tiap MF, selanjutnya dilakukan proses 'defuzzification', di mana klasifikasi ditentukan berdasarkan nilai tertinggi untuk tiap MF. Misalnya bila nilai Q5 (lihat indeks MF pada tabel 1) paling tinggi dibandingkan nilai $Q$ yang lain, maka hydrometeor tersebut termasuk dalam kategori hail. Presipitasi kemudian dapat ditampilkan dengan beberapa warna yang menunjukkan kode precipitation identification (PID) berdasarkan hasil defuzzification dari metode FL.

\section{HASIL DAN PEMBAHASAN}

Gambar 4, 5 dan 6 masing-masing menunjukkan produk CAPPI di wilayah $A$ untuk parameter Zh, ZDR dan KDP serta hasil metode HDR, CM dan FL, masing-masing untuk ketinggian $500 \mathrm{~m}, 2 \mathrm{~km}$ dan $5 \mathrm{~km}$, sedangkan gambar 7, 8 dan 9 menunjukkan hal yang sama untuk wilayah B.

Parameter Zh pada kedua wilayah menunjukkan pita presipitasi dengan nilai $\mathrm{Zh}$ melebihi $40 \mathrm{dBZ}$, sedangkan ZDR menunjukkan nilai positif $(Z D R>0 \mathrm{~dB})$ hanya pada salah satu sisi pita presipitasi yang searah dengan pergerakan presipitasi, yaitu di sisi timur untuk wilayah $\mathrm{A}$, dan sisi utara untuk wilayah $B$, yang mengindikasikan wilayah presipitasi tersebut bertipe hujan dengan intensitas tinggi. Hal ini juga dikonfirmasi dengan parameter KDP yang dominan positif pada wilayah pita dengan reflektivitas tinggi, dengan KDP mencapai 3-5\% $/ \mathrm{km}$. Perbedaan nilai ZDR antara dua sisi pita presipitasi tersebut menunjukkan karakter awan cumulonimbus (Cb) pada fase matang, dengan presipitasi terjadi pada salah satu sisi, sedangkan updraft mendominasi sisi lainnya. Daerah perbatasan antara sisi presipitasi dengan sisi updraft memiliki nilai $\mathrm{Zh}$ lebih rendah, berkisar antara $20-30 \mathrm{dBZ}$, dengan ZDR dan KDP negatif. Hal ini dapat berarti dua hal wilayah tersebut memiliki presipitasi berjenis hujan ringan, atau es dengan diameter relatif kecil. Daerah inilah yang akan diuji dengan metode HDR, CM dan FL.

Metode HDR menunjukkan distribusi nilai positif yang dominan (2-8 dB), yang mengindikasikan adanya presipitasi berjenis es pada lokasi A dan B. Namun di sisi lain, metode CM nenunjukkan nilai KDP yang tidak konsisten dan dominan pada perbatasan wilayah presipitasi ( $\mathrm{h} \mathrm{h}<20 \mathrm{dBZ}$ ), dengan nilai maksimum mencapai $0.03 \% \mathrm{~km}$. Hal ini mengindikasikan tidak adanya jejak es pada wilayah presipitasi tersebut. Hasil yang berbeda antara metode HDR dan CM diduga merupakan akibat dari diameter es yang relatif kecil pada wilayah presipitasi, sehingga tidak signifikan untuk terdeteksi oleh metode CM. Sebagai perbandingan, nilai HDR yang mengindikasikan hail mencapai $30 \mathrm{~dB}$ (Aydin et al., 1986) dan KDP inkonsisten melebihi $15 \% / \mathrm{km}$ (Smyth et al., 1999; Vivekanandan et al., 2003).

Metode FL menunjukkan beberapa jenis hydrometeor, dengan tipe hujan ringan atau drizzle $(P I D=1)$ dan hujan $(P I D=2)$ mendominasi pita presipitasi di wilayah $A$ dan $B$, sedangkan graupel dan hail terlihat pada perbatasan pita presipitasi, serta daerah batas antara sisi presipitasi dan updraft. Hydrometeor es yang terdeteksi metode FL memiliki distribusi lebih besar dibandingkan metode HDR, karena metode FL yang digunakan dalam penilitian ini membagi spesies es ke dalam tiga kelas kategori (graupel, campuran hujan-hail dan hail), sedangkan HDR tidak memperhitungkan perbedaan tersebut. Selain itu, metode FL hanya memanfaatkan perbedaan karakter jenis presipitasi berdasarkan parameter Zh, ZDR dan KDP, tanpa memperhitungkan probabilitas terjadinya hail seperti pada metode HDR dan CM. Hasil metode FL juga menunjukkan peningkatan distribusi graupel dengan bertambahnya ketinggian bila dibandingkan dengan hujan yang tidak begitu terlihat dengan metode HDR dan CM. 

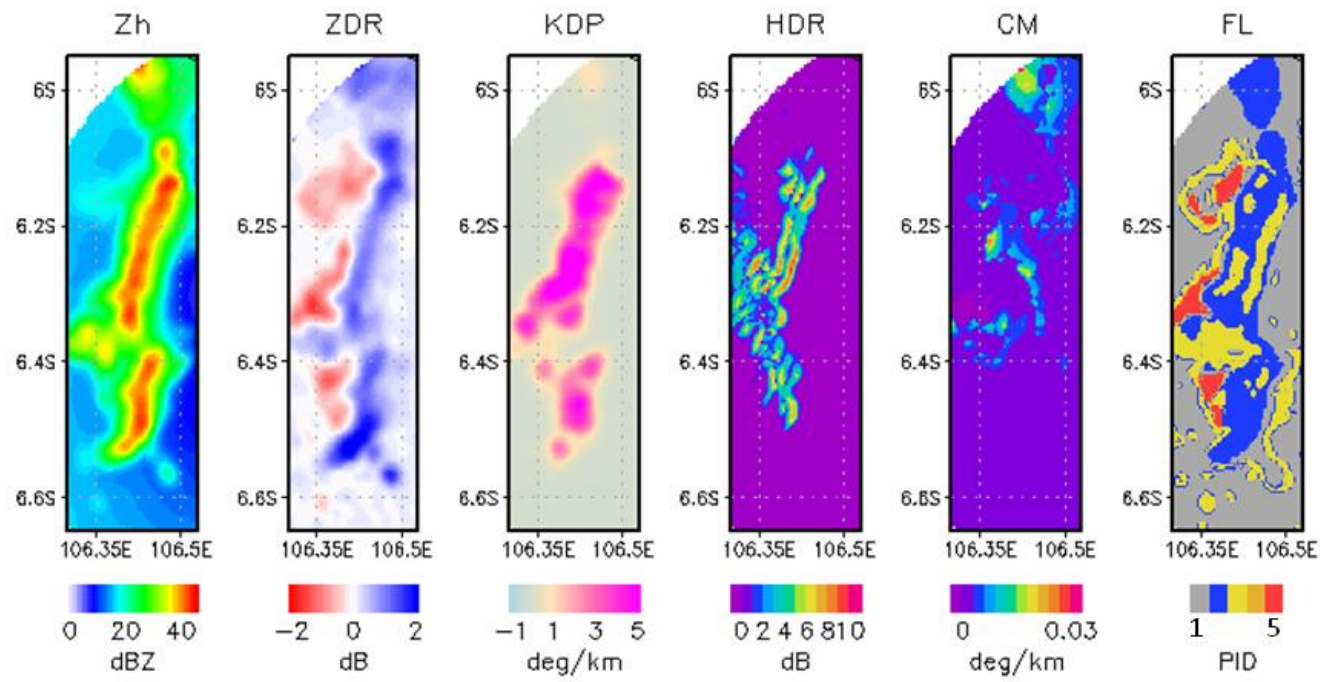

Gambar 4. Produk CAPPI untuk wilayah A pada ketinggian 500 m
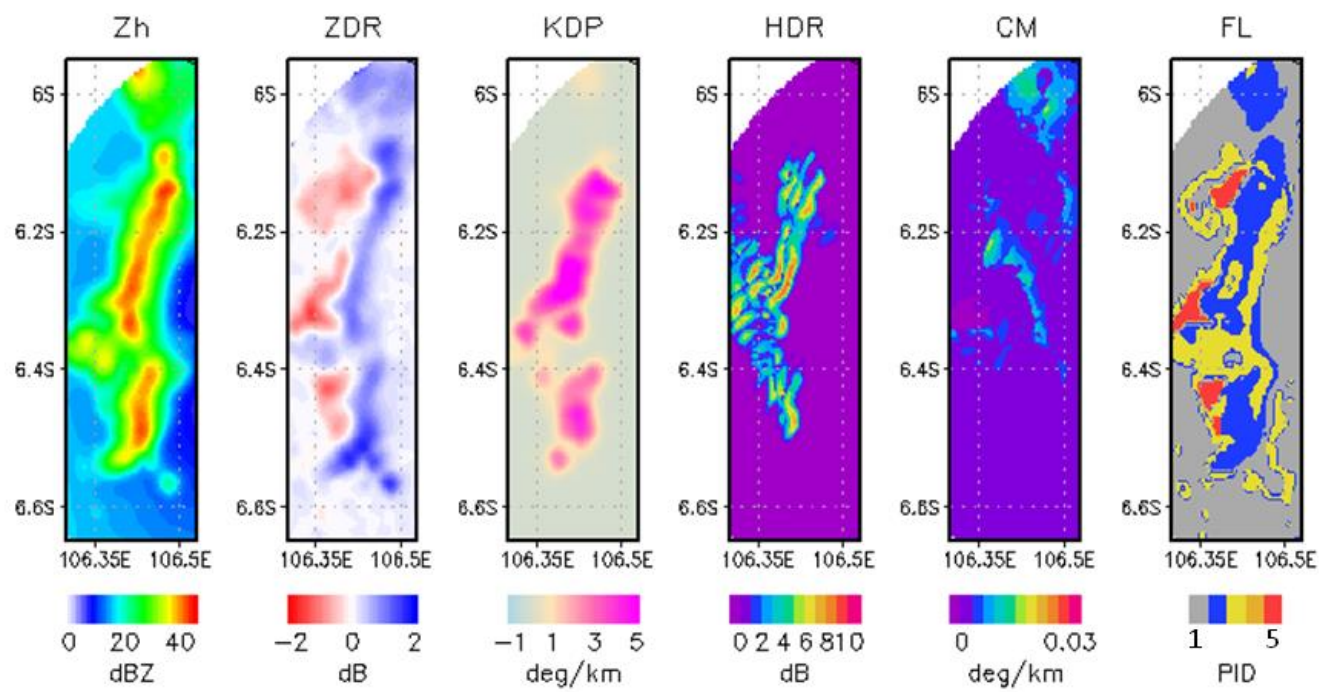

Gambar 5. Produk CAPPI untuk wilayah A pada ketinggian $2 \mathrm{~km}$
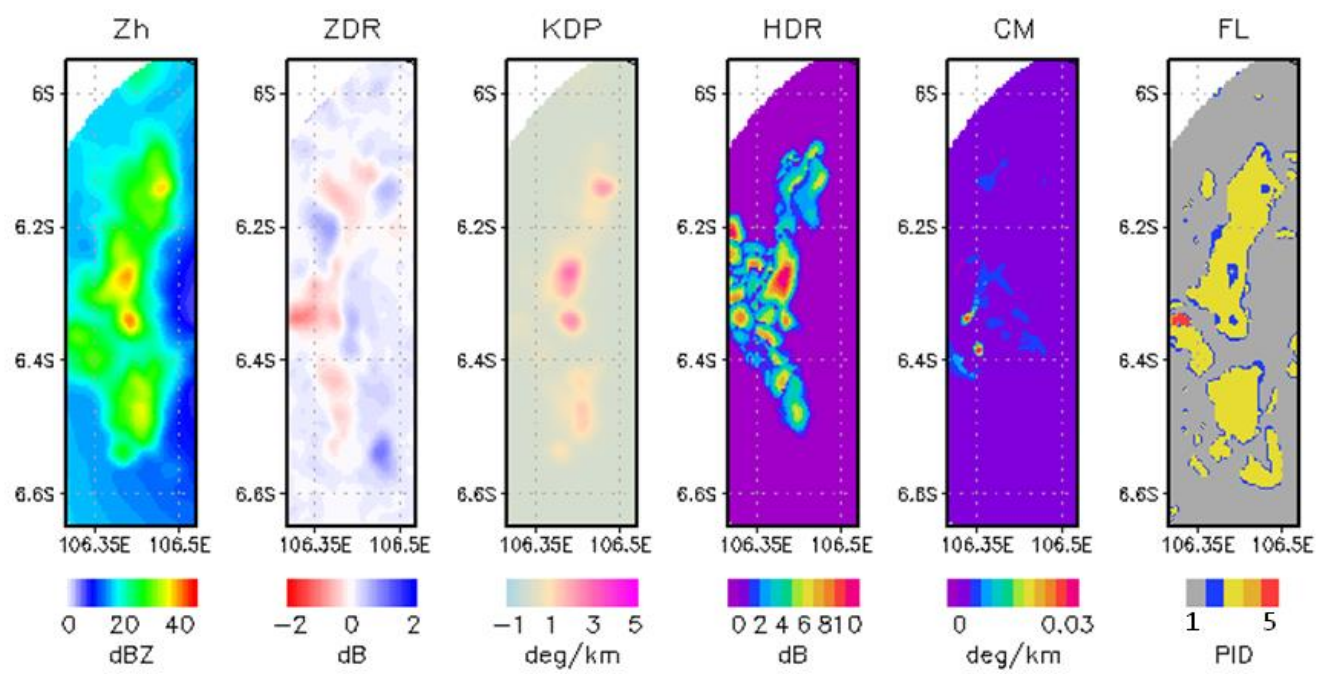

Gambar 6. Produk CAPPI untuk wilayah A pada ketinggian $5 \mathrm{~km}$ 
$\mathrm{Zh}$

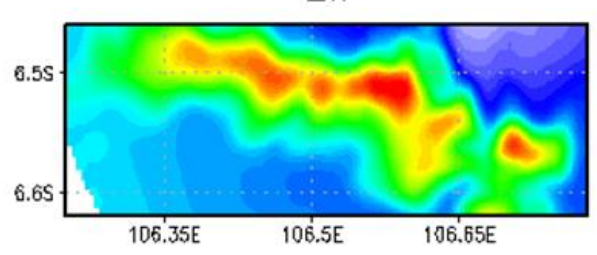

ZDR

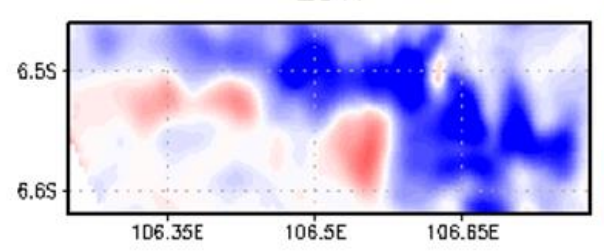

KDP

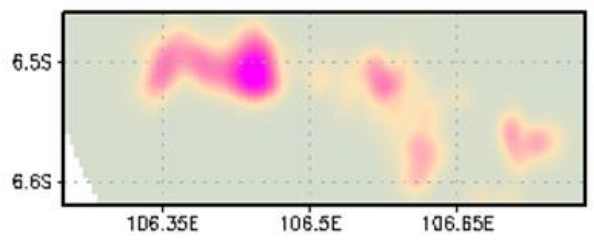

HDR

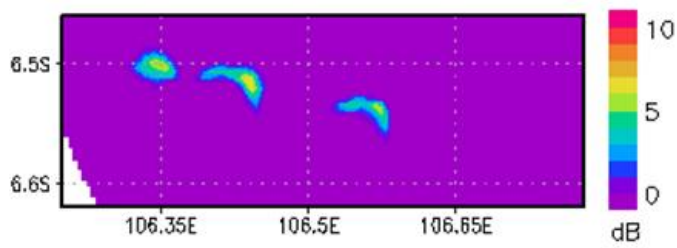

$\mathrm{CM}$

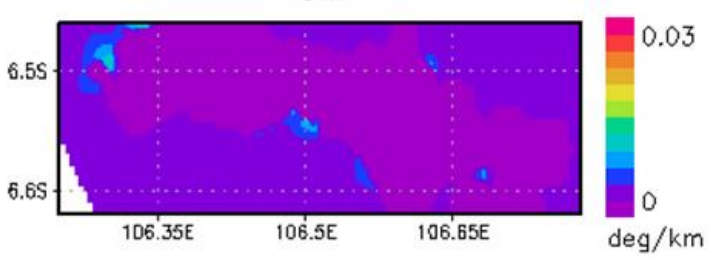

FL

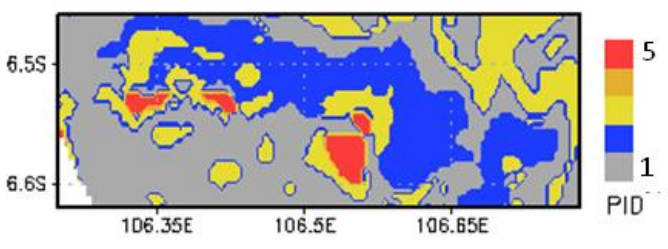

Gambar 7. Produk CAPPI untuk wilayah B pada ketinggian 500 m

$\mathrm{Zh}$
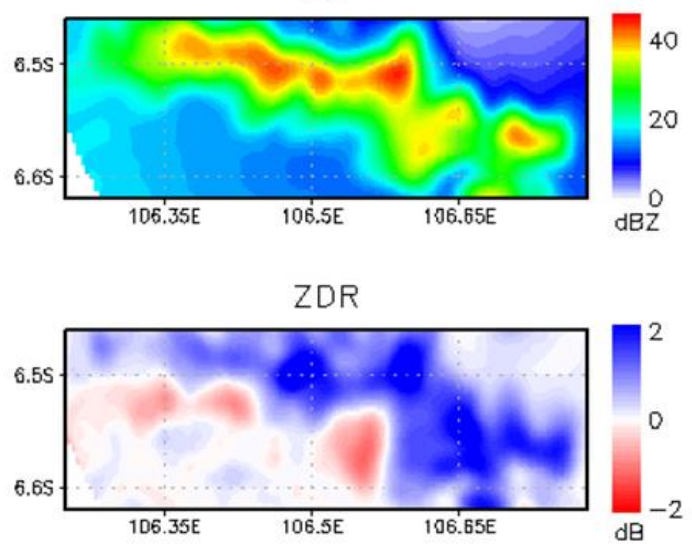

KDP

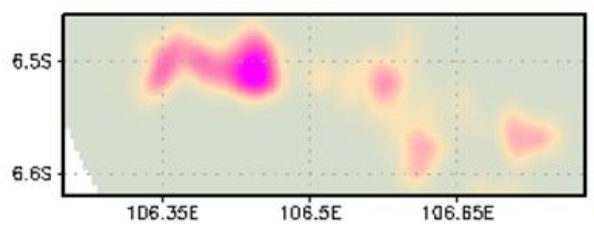

HDR

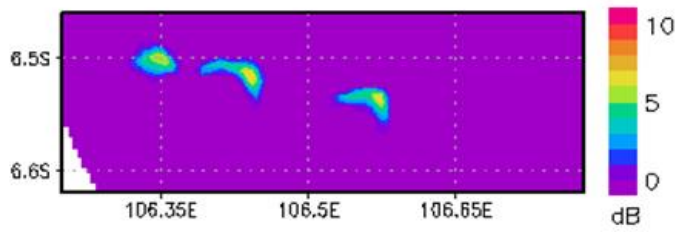

$\mathrm{CM}$

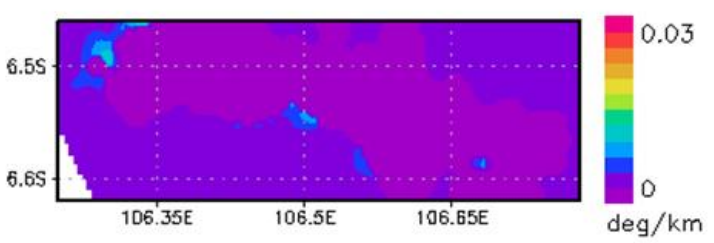

FL

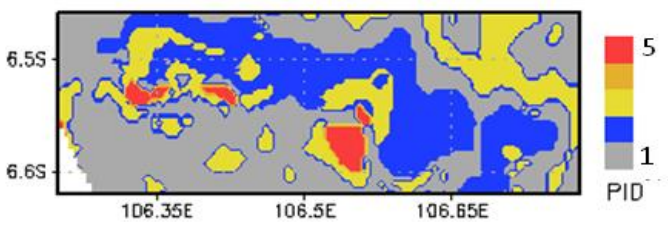

Gambar 8. Produk CAPPI untuk wilayah A pada ketinggian 2 km 
$\mathrm{Zh}$

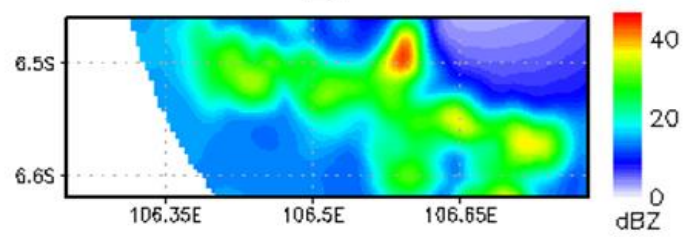

ZDR

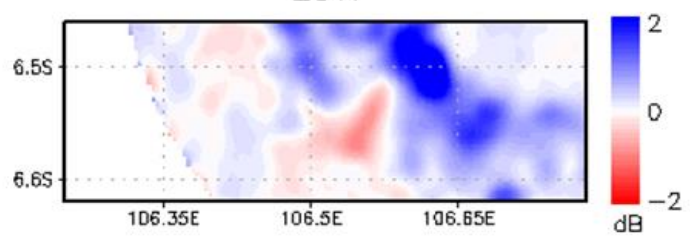

KDP

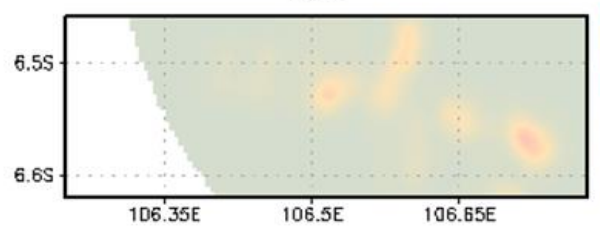

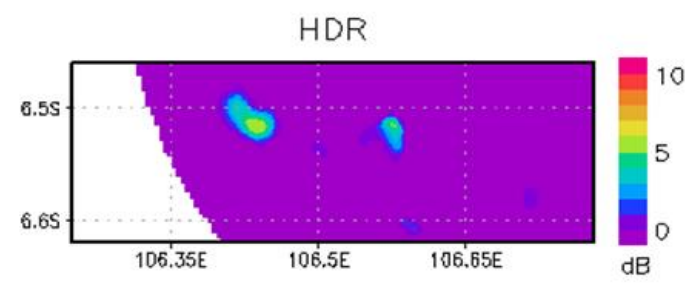

$\mathrm{CM}$

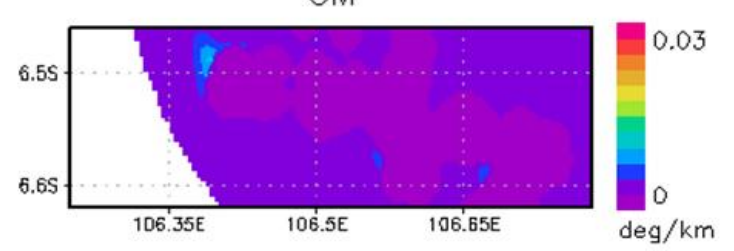

FL

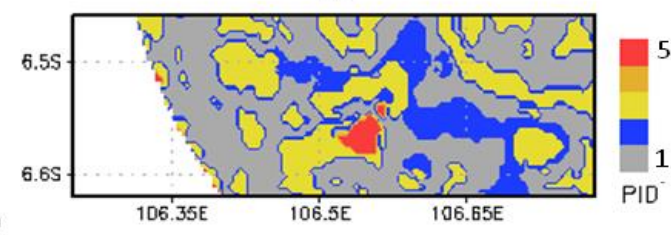

Gambar 9. Produk CAPPI untuk wilayah A pada ketinggian 5 km

Gambar 10 dan 11 masing-masing menampilkan irisan vertikal produk CAPPI pada wilayah $A$ dan $B$ (garis $\alpha$ dan $\beta$ ), mulai dari ketinggian $500 \mathrm{~m}$ hingga $15 \mathrm{~km}$. Kedua gambar tersebut menunjukkan nilai Zh positif, ZDR positif dan KDP positif yang dominan pada lapisan di bawah $5 \mathrm{~km}$ yang mengindikasikan daerah tersebut didominasi oleh hujan dengan intensitas tinggi. Jejak keberadaan es terlihat pada daerah dengan ZDR negatif dan pada lapisan di atas $5 \mathrm{~km}$, seperti yang ditunjukkan oleh metode HDR. Seperti sebelumnya, metode CM tidak menunjukkan adanya jejak es yang signifikan, terutama pada wilayah A. Namun pada wilayah B, metode CM mengindikasikan adanya jejak es pada ketinggian $8-10 \mathrm{~km}$. Hasil serupa juga ditunjukkan oleh metode HDR dan FL pada daerah yang sama $\left(105.8^{\circ} \mathrm{E}\right)$, walaupun pada ketinggian yang relatif berbeda dengan metode CM. Di sisi lain, metode FL menunjukkan dominasi graupel dan hujan pada kedua wilayah, dengan jejak hail pada beberapa daerah. Hasil metode FL seluruhnya menunjukkan tidak adanya campuran hujan-hail $(P I D=4)$ pada kedua wilayah yang diamati.

Dari ketiga algoritma yang digunakan, metode HDR memberikan hasil deteksi yang paling konsisten, dengan kontur yang jelas terhadap nilai diferensial hail pada beberapa daerah yang memiliki jejak es. Hal ini disebabkan karena hasil metode HDR lebih banyak ditentukan oleh parameter Zh dan ZDR, tanpa kontribusi parameter KDP. Selain itu, metode ini hanya melakukan klasifikasi terhadap dua jenis presipitasi dasar, yaitu hujan dan hail. Seperti halnya metode HDR, metode CM juga hanya melakukan klasifikasi untuk hujan dan hail, namun menggunakan KDP sebagai salah satu parameter untuk menguji konsistensi parameter Zh dan ZDR, sehingga cenderung memberikan hasil yang berbeda dengan dengan metode HDR yang tidak menggunakan parameter KDP. Hasil metode CM seluruhnya menunjukkan jejak hail yang minim pada kedua kejadian presipitasi yang diamati. Hal ini diduga karena diameter hail pada kedua kejadian tersebut relatif kecil yang ditunjukkan oleh nilai $\mathrm{HDR}<10 \mathrm{~dB}$ dan inkonsistensi KDP $<$ $0.03 \% \mathrm{~km}$. Dibandingkan metode HDR dan CM, metode FL memberikan klasifikasi yang paling lengkap terhadap hydrometeor dari spesies es, namun metode ini sangat bergantung kepada membership function (MF) yang digunakan. MF yang digunakan pada penelitian ini menggunakan referensi yang digunakan pada studi-studi deteksi es sebelumnya (Al-Sakka et al., 2013; Dolan \& Rutledge, 2009; Kouketsu et al., 2015; Mahale et al., 2014; Vivekanandan et al., 1999, 2003), yang dilakukan pada daerah dengan kareaktersitik yang berbeda dengan lokasi studi saat ini, sehingga berpotensi memberikan bias pada hasil analisis dengan metode FL. Hal ini diperkuat oleh tidak ditemukannya campuran hujan-hail $(\mathrm{PID}=4)$ pada setiap ketinggian. Dengan demikian, validasi dengan menggunakan pengukuran in-situ seperti penakar atau disdrometer perlu dilakukan sebelum menentukan MF yang digunakan untuk klasifikasi presipitasi dengan metode FL.

Berdasarkan hasil observasi dan analisis dari metode yang digunakan, tidak ditemukan adanya konsentrasi es yang cukup signifikan untuk menghasilkan hujan es, walaupun radar mendeteksi kejadian thunderstorm pada lokasi 


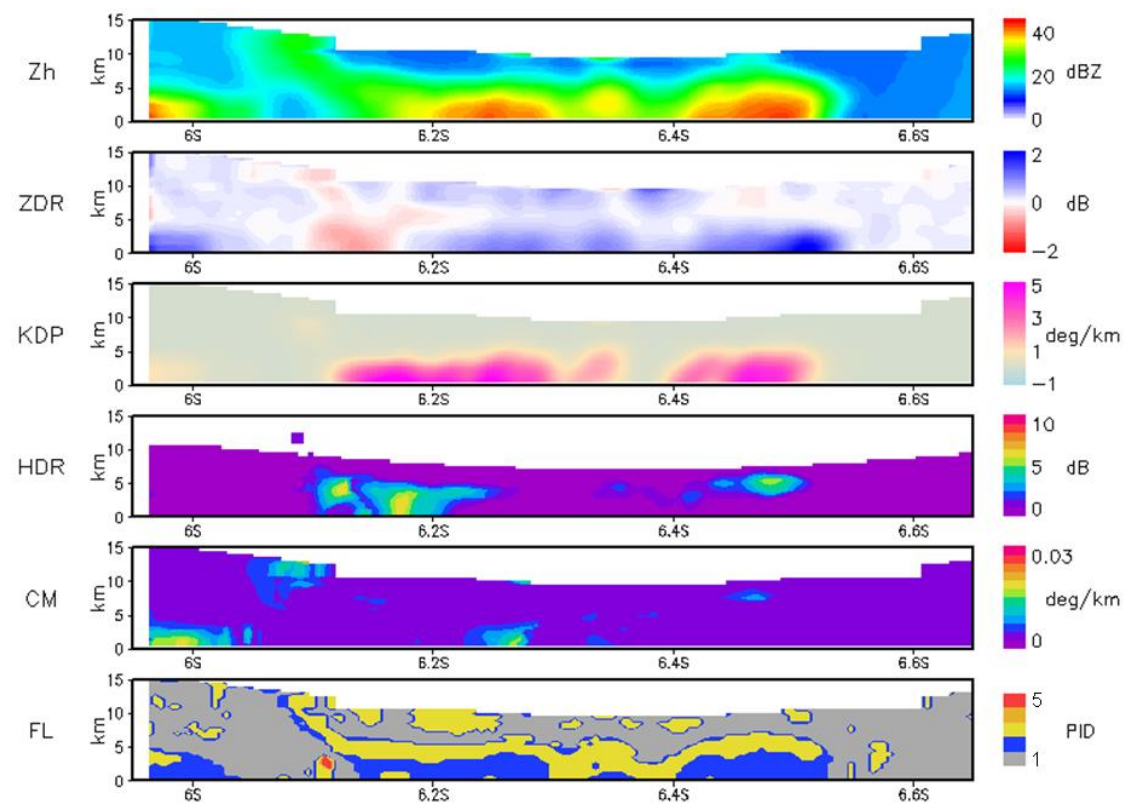

Gambar 10. Irisan vertikal untuk wilayah A (garis a pada gambar 1) dari ketinggian $500 \mathrm{~m}-15 \mathrm{~km}$

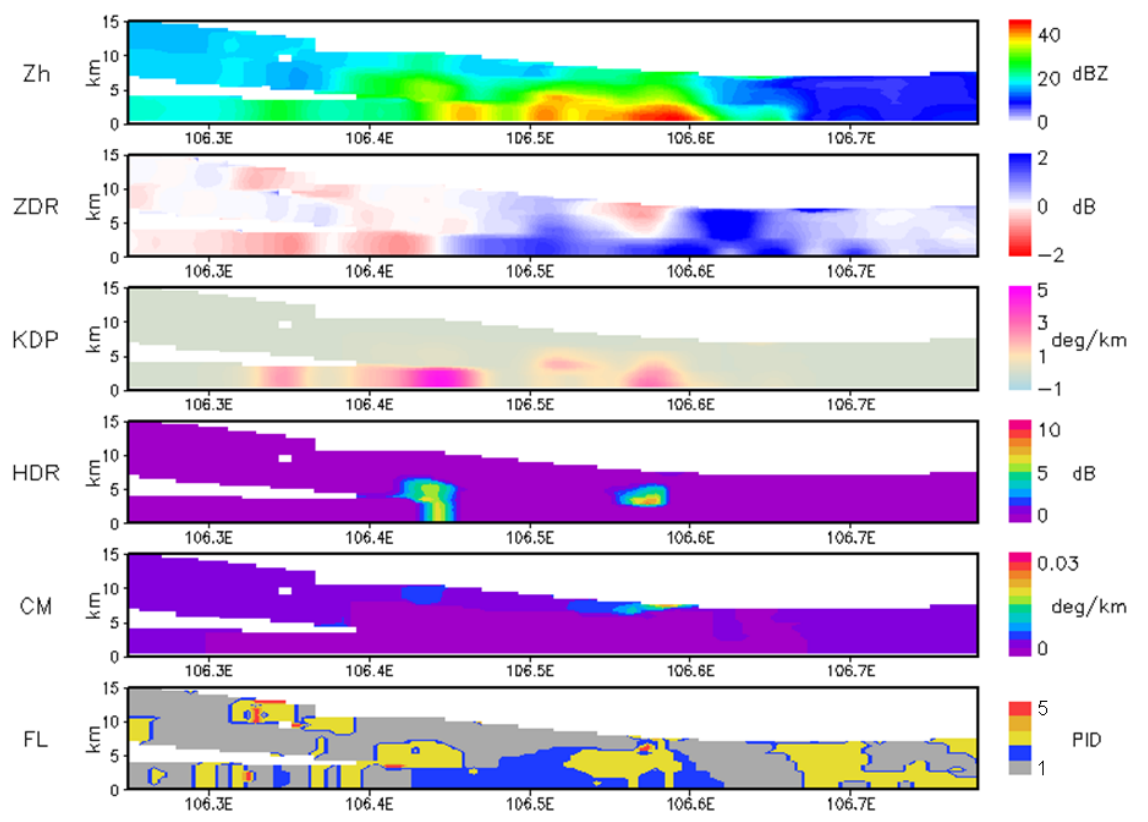

Gambar 11. Irisan vertikal untuk wilayah B (garis $\beta$ pada gambar 1) dari ketinggian $500 \mathrm{~m}-15 \mathrm{~km}$.

pengamatan. Hal ini juga dikonfirmasi dengan tidak adanya laporan kejadian hujan es berdasarkan data SYNOP dari stasiun BMKG Serang, Curug Budiarto dan Citeko pada periode tersebut. Hal ini diduga akibat puncak presipitasi pada awan (echo tops) di atas $45 \mathrm{dBZ}$, hanya mencapai ketinggian kurang dari $5 \mathrm{~km}$. Hujan es di wilayah Indonesia umumnya terjadi pada awan $\mathrm{Cb}$ dengan puncak awan yang tinggi, dengan suhu $(-60){ }^{\circ} \mathrm{C}-(-70)^{\circ} \mathrm{C}$, dan echo tops di atas 50 dBZ (Paski et al., 2017).

\section{KESIMPULAN}

Radar polarimetrik merupakan instrumen pengamatan cuaca yang memungkinkan identifikasi jenis hydrometeor yang sebelumnya sukar dilakukan oleh radar konvensional (nonpolarimetrik). Bentuk dan konsentrasi hydrometeor, terutama dari jenis hujan dan hail, dapat dideteksi dengan memanfaatkan tiga parameter polarimetrik dari radar Furuno WR2100, yaitu: Zh, ZDR dan KDP. Berdasarkan hasil analisis deteksi es dengan menggunakan tiga algoritma yang berbeda, diperoleh beberapa kesimpulan sebagai berikut:

1. Metode reflektivitas diferensial hail (HDR) memberikan hasil yang paling sensitif dalam mengidentifikasi keberadaan es di atmosfer, namun hanya mampu melakukan klasifikasi terhadap dua jenis hydrometeor saja, yaitu: hujan dan hail. Signifikansi dari hail yang terdeteksi ditunjukkan oleh nilai HDR yang 
diperoleh, makin besar nilai positif HDR, makin signfikan konsentrasi hail yang terdeteksi oleh radar.

2. Metode konsistensi KDP (CM), seperti halnya metode HDR, hanya mampu melakukan klasifikasi terhadap hujan dan hail, dan memiliki sensitivitas paling rendah dibandingkan metode lain dalam penelitian ini. Hal ini diduga akibat keberadaan es yang tidak signifikan pada kedua wilayah pengamatan, seperti yang ditunjukkan oleh nilai HDR yang lebih rendah dari $10 \mathrm{~dB}$ dan inkonsistensi KDP di bawah $0.03 \% / \mathrm{km}$. Keduanya jauh di bawah nilai yang diperoleh pada studi sebelumnya, dengan nilai HDR yang mengindikasikan hail mencapai 30 dB (Aydin et al., 1986) dan inkonsistensi KDP melebihi $15 \% / \mathrm{km}$ (Smyth et al., 1999; Vivekanandan et al., 2003).

3. Metode fuzzy logic (FL) memberikan klasifikasi hydrometeor yang paling lengkap dibandingkan metode yang lain, namun rentan terhadap bias dan sangat bergantung pada membership function (MF) yang digunakan. MF sendiri sangat bergantung kepada validasi in-situ terhadap jenis hydrometeor yang dideteksi dan karakter wilayah pengamatan.

4. Berdasarkan parameter Zh, ZDR dan KDP serta ketiga metode deteksi es yang digunakan dalam penelitian ini, dapat disimpulkan bahwa tidak terdapat konsentrasi es yang signifikan pada kejadian presipitasi tanggal 24 Januari 2016 dan 14 Februari 2016, akibat echo tops awan $\mathrm{Cb}$ di atas $45 \mathrm{dBZ}$, hanya mencapai ketinggian kurang dari $5 \mathrm{~km}$.

\section{DAFTAR PUSTAKA}

Arbain, A.A., Renggono, F., Yahya, R.B. (2017). Pengaruh Madden-Julian Oscillation Terhadap Distribusi Temporal dan Propagasi Hujan Berdasarkan Pengamatan Radar Cuaca (Studi Kasus: Intensive Observation Period 2016 di Wilayah Jakarta dan Sekitarnya). Jurnal Sains \& Teknologi Modifikasi Cuaca, 18(2), 43-50. doi: 10.29122/jstmc.v18i2.2058

Al-Sakka, H., Boumahmoud, A.A., Fradon, B., Frasier, S.J., Tabary, P. (2013). A New Fuzzy Logic Hydrometeor Classification Scheme Applied to the French X-, C-, and S-band Polarimetric Radars. Journal of Applied Meteorology and Climatology, 52(10), 2328-2344. doi: 10.1175/JAMC-D12-0236.1

Ali, A., Hidayati, S. (2015). Peringatan Dini Potensi Hujan Es Menggunakan Metode Severe Hail Index Berdasarkan Pengamatan Radar Cuaca Doppler. Prosiding Seminar Nasional Fisika (E-Journal) SNF2015.

Aydin, K., Seliga, T.A., Balaji, V. (1986). Remote Sensing of Hail with a Dual Linear Polarization Radar. Journal of Climate and Applied Meteorology, 25(10), 1475-1484. doi:

$10.1175 / 1520$

0450(1986)025<1475:RSOHWA>2.0.CO;2

Dolan, B., Rutledge, S.A. (2009). A Theory-Based Hydrometeor Identification Algorithm for XBand Polarimetric Radars. Journal of Atmospheric and Oceanic Technology, 26(10), 2071-2088. doi: 10.1175/2009JTECHA1208.1

Golbon-Haghighi, M.H., Zhang, G., Li, Y., Doviak, R.J. (2016). Detection of Ground Clutter from Weather Radar Using A DualPolarization And Dual-Scan Method. Atmosphere, 7(6), 1-11. doi: 10.3390/atmos7060083

Grazioli, J., Tuia, D., Berne, A. (2015). Hydrometeor Classification from Polarimetric Radar Measurements: A Clustering Approach. Atmospheric Measurement Techniques, 8(1). 149-170. doi: 10.5194/amt-8-149-2015

Kouketsu, T., Uyeda, H., Ohigashi, T., Oue, M., Takeuchi, H., Shinoda, T., Tsuboki, K., Kubo, M., Muramoto, K. (2015). A Hydrometeor Classification Method for XBand Polarimetric Radar: Construction and Validation Focusing on Solid Hydrometeors Under Moist Environments. Journal of Atmospheric and Oceanic Technology, 32(11), 2052-2074. doi: 10.1175/JTECHD-14-00124.1

Kunz, M., Kugel, P.I.S. (2015). Detection of Hail Signatures from Single-Polarization C-Band Radar Reflectivity. Atmospheric Research, 153, 565-577. doi: 10.1016/j.atmosres.2014.09.010

Leitao, M. J., \& Watson, P. A. (1984). Application of Dual Linearly Polarized Radar Data to Prediction of Microwave Path Attenuation at 10-30 GHz. Radio Science, 19(1), 209-221. doi: 10.1029/RS019i001p00209

Mahale, V. N., Zhang, G., Xue, M. (2014). Fuzzy Logic Classification of S-Band Polarimetric Radar Echoes to Identify Three-Body Scattering and Improve Data Quality. Journal of Applied Meteorology and Climatology, 53(8), 2017-2033. doi: 10.1175/JAMC-D-13-0358.1

Mori, S., Hamada, J., Sakurai, N., Fudeyasu, H., Kawashima, M., Hashiguchi, H., Syamsudin, F., Arbain, A.A., Sulistyowati, R., Matsumoto, J., Yamanaka, M.D. (2011). Convective Systems Developed along the Coastline of Sumatera Island, Indonesia, Observed with an X-band Doppler Radar during the HARIMAU2006 Campaign. Journal of the Meteorological Society of Japan, 89, 61-81. doi: 10.2151/jmsj.2011A04

Paski, J.A.I., Permana, D.S., Sepriando, A., Pertiwi, D.A.S. (2017). Analisis Dinamika Atmosfer Kejadian Hujan Es Memanfaatkan Citra Radar dan Satelit Himawari-8 (Studi Kasus: Tanggal 3 Mei 2017 di Kota 
Bandung). Seminar Nasional Penginderaan Jauh ke-4 Tahun 2017.

Ribaud, J.F., Bousquet, O., Coquillat, S., Al-Sakka, H., Lambert, D., Ducrocq, V., Fontaine, E. (2016). Evaluation and Application of Hydrometeor Classification Algorithm Outputs Inferred from Multi-Frequency Dual-Polarimetric Radar Observations Collected during HyMeX. Quarterly Journal of the Royal Meteorological Society, 142. doi: 10.1002/qj.2589

Smyth, T.J., Blackman, T.M., Illingworth, A.J. (1999). Observations of Oblate Hail using Dual Polarization Radar and Implications for Hail-detection Schemes. Quarterly Journal of the Royal Meteorological Society, 125(555), 993-1016. doi: 10.1002/qj.49712555512

Vivekanandan, J., Zhang, G., Ellis, S.M., Rajopadhyaya, D., Avery, S.K. (2003). Radar Reflectivity Calibration using Differential Propagation Phase
Measurement. Radio Science, 38(3). doi: 10.1029/2002RS002676

Vivekanandan, J., Zrnic, D.S., Ellis, S.M., Oye, R., Ryzhkov, A.V., Straka, J. (1999). Cloud Microphysics Retrieval using S-Band DualPolarization Radar Measurements. Bulletin of the American Meteorological Society, 80(3), 381-388. doi: 10.1175/15200477(1999)080<0381:CMRUSB >2.0.CO;2

Witt, A., Nelson, S.P. (1991). The Use of SingleDoppler Radar for Estimating Maximum Hailstone Size. Journal of Applied Meteorology, 30(4). 425-431. doi: $10.1175 / 1520-$ 0450(1991)030<0425:TUOSDR>2.0.CO;2

Wu, P., Arbain, A.A., Mori, S., Hamada, J., Hattori, M., Syamsudin, F., Yamanaka, M.D. (2013). The Effects of an Active Phase of the Madden-Julian Oscillation on the Extreme Precipitation Event over Western Java Island in January 2013. SOLA. doi: 10.2151/sola.2013-018 